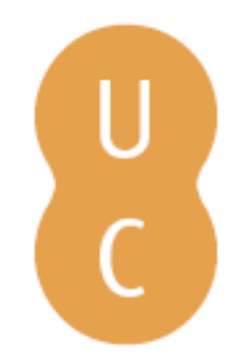

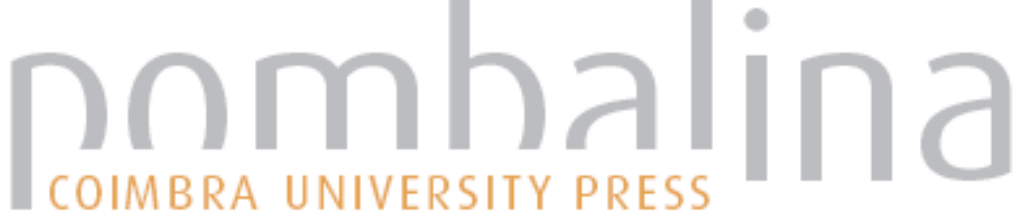

\section{As recriações históricas em Portugal: perspetivas e impatos}

\author{
Autor(es): $\quad$ Reis, Roberto \\ Publicado por: Imprensa da Universidade de Coimbra \\ URL \\ persistente: URI:http://hdl.handle.net/10316.2/37376 \\ DOI: $\quad$ DOI:http://dx.doi.org/10.14195/978-989-26-0754-2_10
}

Accessed : $\quad$ 26-Apr-2023 09:30:27

A navegação consulta e descarregamento dos títulos inseridos nas Bibliotecas Digitais UC Digitalis, UC Pombalina e UC Impactum, pressupõem a aceitação plena e sem reservas dos Termos e Condições de Uso destas Bibliotecas Digitais, disponíveis em https://digitalis.uc.pt/pt-pt/termos.

Conforme exposto nos referidos Termos e Condições de Uso, o descarregamento de títulos de acesso restrito requer uma licença válida de autorização devendo o utilizador aceder ao(s) documento(s) a partir de um endereço de IP da instituição detentora da supramencionada licença.

Ao utilizador é apenas permitido o descarregamento para uso pessoal, pelo que o emprego do(s) título(s) descarregado(s) para outro fim, designadamente comercial, carece de autorização do respetivo autor ou editor da obra.

Na medida em que todas as obras da UC Digitalis se encontram protegidas pelo Código do Direito de Autor e Direitos Conexos e demais legislação aplicável, toda a cópia, parcial ou total, deste documento, nos casos em que é legalmente admitida, deverá conter ou fazer-se acompanhar por este aviso.

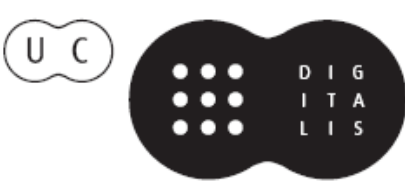




\section{ROBERTO REIS}

CEGOT, Universidade de Coimbra

roberto.reis34@gmail.com

\section{AS RECRIAÇÕES HISTÓRICAS EM PORTUGAL}

\section{- PERSPETIVAS E IMPATOS}

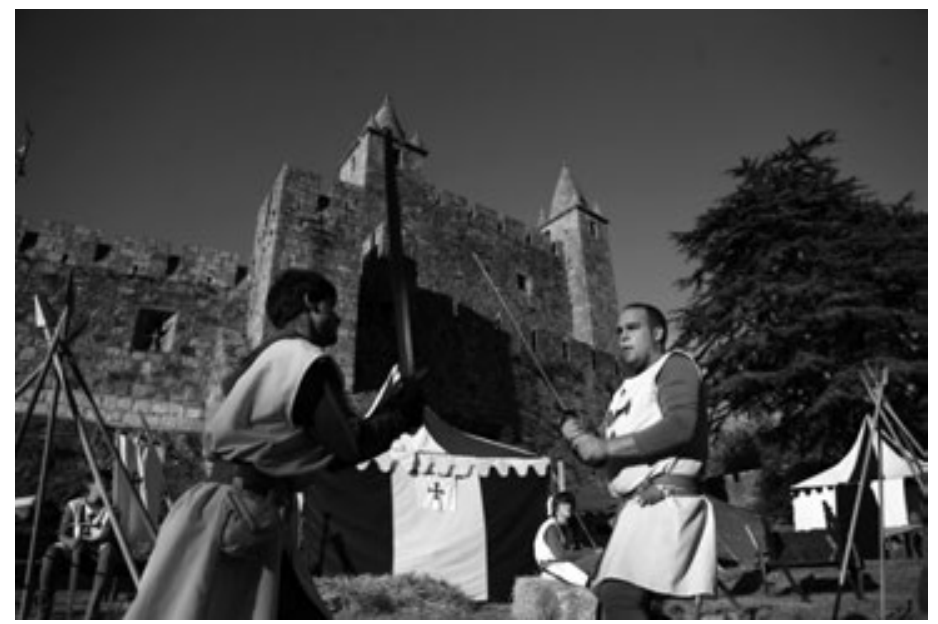

FIG. 1 - Viagem Medieval em Terra de Santa Maria Fonte: Arquivo Viagem Medieval em Terra de Santa Maria

\section{Introdução}

O Turismo Cultural não assenta exclusivamente na procura de eventos ou experiências culturais. Antes circunscrever-se-á numa espécie de geometria triangular, a qual envolve, para além dos aspetos culturais patrimoniais, a fruição de valores patrimoniais culturais, assim como um mosaico de atividades ligadas à prática do turismo. Tal multidimensionalidade reflete uma ligação mais estreita do que nunca entre o turismo dito cultural, ou 
seja, o turismo ligado aos objetos patrimoniais e o turismo dito de eventos, isto é o turismo ligado às recriações históricas.

Este artigo terá como objetivo discutir e aprofundar o conceito de Recriações Históricas, tendo por base a bibliografia, e a reflexão sobre a habitual tendência de revalorização dos principais locais de recriação sobre a temática medieval e respetivas zonas envolventes, como reforço da atratividade dos destinos turísticos.

Tendo como pano de fundo as recriações enquanto viagem em busca exclusiva do passado, registam-se dificuldades em identificar caraterísticas verdadeiramente diferenciadoras entre recriação histórica, reenatement e living history, considerando que todos eles têm como objetivo a recriação do passado.

Quer o turista, quer o participante são atraídos pelo autêntico e pelo tradicional.

Ambos visitam os diversos lugares numa tentativa de satisfazer desejos nostálgicos como forma de consolidar e de ligar à terra um património cultural secular.

Ambos se fixam numa espécie de alienação romântica, embora conscientes de que o real e o natural são culturalmente construídos. O que diferencia um e outro são as suas motivações mais profundas.

Por sua vez, a comercialização dos destinos de Recriação Histórica leva os responsáveis dos destinos a valorizar o seu património e a potenciá-lo com ofertas culturais diversificadas nos espaços envolventes, que extravasam as tradicionais festividades e eventos de recriação histórica.

Neste sentido, procurar-se-á desenvolver ao longo deste trabalho uma reflexão sobre a realidade atual do produto Turismo de Eventos/Recriações Históricas, tendo como foco central o patrimonial, cultural e suportado por três componentes estruturais, designadamente património, cultural e turística. Esta nova abordagem obriga a uma reflexão mais aprofundada de qual deve ser o posicionamento deste produto turístico, que parece deter um poder de atração singular para a competitividade dos destinos turísticos. 


\section{As Recriações Históricas}

As recriações históricas têm conhecido uma grande expansão nos últimos anos em Portugal, pelo que se justifica o debate sobre este fenómeno - quer para melhor conhecimento intrínseco, quer para divulgação dos instrumentos a si associados.

Neste contexto temos que considerar os seguintes conceitos dentro da "Recriação Histórica", a "Living History" que é a redescoberta do passado em todas as suas modalidades (civil, tecnológica, científica, artística ou militar) e numa perspetiva mais ampla, e o conceito "Re-enactment» que significa a recriação de um determinado evento histórico sobre o qual colocam em cena os fatos e os seus desenvolvimentos; nomeadamente os eventos bélicos (batalha de Hasting ou a de Aljubarrota), entre outras.

Está claro que, por norma, todos os grupos, associações ou simplesmente pessoas empenhadas na "Recriação Histórica" fazem comummente "Living History", enquanto, os que recriando apenas um preciso evento histórico, fazem aquilo que designamos de "Re-enactment".

Na perspetiva de Mabel Villagra Romero no seu trabalho "Actualidad del Asociacionismo Recreacionista en Europa: el caso italiano", para se poder definir como sendo de "Recriação Histórica" um grupo, uma associação ou uma pessoa a título individual devem de respeitar os seguintes requisitos:

a) reconstruir rigorosamente através dos mais diversos aspetos (vida quotidiana, eventos bélicos, religiosos ou civis, música, artes de rua, etc.) um período histórico bem definido, representando o melhor possivel e segundo estudos, textos, documentos da época e investigação arqueológica.

o que deve de suceder é declarar de modo evidente e explícito o período histórico recriado, para por exemplo produzirem adequadamente os seus trajes (civis ou militares), o equipamento e alfaias".

Ao nível do associativismo, muitos destes grupos constituem-se local ou regionalmente como associações histórico-culturais, associações desportivo-culturais ("grupos históricos"), associações histórico-religiosas. Noutros casos, numa situação parecida com a Espanha, temos as Câmaras Municipais e as entidades locais que se encarregam de organizar este tipo de eventos coordenar as associações e outros participantes. 
Na perspetiva da mesma autora, podemos então definir as seguintes categorias para os grupos de recriação histórica: Grupos locais (ranchos folclóricos) a que se associam grupos culturais dedicados à recriação de eventos de caráter histórico, religioso ou desportivo (como por exemplo jogos de petanca); Grupos históricos de combatentes que na sua grande maioria integram também praticantes de esgrima medieval (numa faceta mais desportiva).

Também encontramos casos de pessoas que movidas pela sua paixão pela história decidem integrar-se, aprender estas técnicas e simultaneamente estabelecer laços de amizades no seio de um grupo; Grupos de recriação histórica enquadrados no "reenactement" ou na "living history". Aqui já estamos a um nível de uma recriação mais científica, muita das vezes assessorada por arqueólogos e professores universitários. Integram os chamados "reennactors", ou "recriadores". Dedicam-se à "reconstrução histórica”, quer na forma de vestir, viver e reproduzir fielmente a partir de vestígios arqueológicos ou de outro tipo de fontes.

Como é referido no Relatório do $1 .^{\circ}$ Encontro sobre Recriação Histórica, Cultura, Turismo e Cidadania que decorreu no Monte do Alto da Courela da Chaminé, em Vendas Novas, em 28 de Novembro de 2008, na comunicação de Catarina Loureiro sob o tema Animação versus Recriação - Incompatibilidade ou Parceria?"Numa época em que as Autarquias se apresentam cada vez mais sensibilizadas, quer para a divulgação do seu património turístico-cultural, quer para memória coletiva da região, urge colocar algumas questões: a imagem dos Municípios, o seu potencial turístico e respetivo desenvolvimento económico.

Os responsáveis e representantes eleitos de um povo, e de um povo com História, ao levarem a cabo iniciativas culturais para as mais variadas $e$ distintas franjas da nossa sociedade, têm por certo consciência das necessidades primeiras daqueles a quem servem"1.

Alexandre Cabrita no mesmo encontro na apresentação " $A$ Recriação Histórica como fator de desenvolvimento local" sublinbou igualmente que "devemos de aproveitar esta "modalidade" cultural, que poderá ter várias

\footnotetext{
1 http://www.passadovivo.com/contactos/Relatorio_1_Encontro_281108.pdf.
} 
valências - na área turística ou da cidadania - de uma forma sustentável, nos tempos que correm pode ser importante para ajudar ao desenvolvimento ou ao "não esquecimento" de certas áreas geográficas, ricas em história e património mas sem grande fator produtivo.

Ao mesmo tempo, compreender a necessidade do envolvimento da comunidade local, através da consciencialização da importância da sua história e de ao torná-la Viva dar corpo a um produto de qualidade, para todos benéficos, pode ser outro instrumento de desenvolvimento de vários setores de uma região.

Todavia é fundamental distinguir o "principal" do "acessório", a "qualidade" do "disfarce", a "dimensão adequada" à "falsa dimensão" são alguns pontos de partida para quem pretenda planear algo dentro deste contexto.

Por último, as recriações históricas devem ser encaradas como projetos globais, sempre a médio-longo prazo, independentemente da sua dimensão e contexto de realização presentes, pautando sempre pela qualidade minimamente exigível ${ }^{2}$.

\section{Histórica: Antes e Depois de 1978}

As Recriações Históricas podem ser simplesmente definidas como "um papel desempenhado, no qual os participantes tentam recriar alguns aspetos de um evento bistórico ou período. Pode ser um periodo estritamente definido, tais como uma guerra específica ou outro evento, ou pode ter uma definição mais ampla ${ }^{3}$."

Segundo esta definição, a reconstituição pode ser de qualquer época ou de qualquer acontecimento histórico, incluindo guerras, que é, sem dúvida, a forma mais conhecida de recriação.

Antes de 1978, a forma mais popular de reconstituição histórica foi a Guerra Civil Americana, que se impôs no início dos anos 60, aquando das comemorações do seu centenário. No entanto, esta não foi a primeira

\footnotetext{
2 Idem.

3 http://en.wikipedia. org/wiki/Historical_reenactment. Acesso em 8 de julho de 2009.
} 
reconstituição histórica que aconteceu. Jenny Thompson, autor do livro "War Games: Inside the World of 20th Century War Reenactors", identificou outras formas de reconstituição que nos levam até ao período do Império Romano ${ }^{4}$.

O conceito Re-enactment (recriação ou reconstituição) é tão antigo quanto a própria civilização, no entender de Howard Giles ${ }^{5}$, que é considerado pelos britânicos como um dos maiores especialistas em eventos históricos. Este autor considera que "as lutas de gladiadores organizadas em Roma, nas quais se lutava até à morte, pelas vitórias no Coliseu”, podem ser consideradas reconstituições históricas primárias, pois um dos principais objetivos da reconstituição é a oferta de uma exibição pública, designada de "história viva".

A História ao Vivo ou Living History, por sua vez, pode ser definida como "uma atividade que incorpora ferramentas históricas, atividades e trajes numa apresentação interativa, fazendo com que os visitantes e os participantes tenham uma sensação de recuar no tempo.”

No século XVII as batalhas de Mock tornaram-se bastante populares. Estas consistiam nas recriações de batalhas em pequena escala para o público em geral ou para a Corte. Em 1635, o grupo London Trained Bands mostrou as suas capacidades de combate perante o rei Carlos I, e em 1645, durante a Guerra Civil Inglesa, as tropas parlamentares escolheram Blackheath para recriarem uma das suas vitórias recentes, apesar de ainda estarem em guerra.

Em 1821, o duque de Buckingham chegou a encenar batalhas navais napoleónicas num lago da sua propriedade. Em 1840, o jovem Lord Glasgow, governador da Nova Zelândia (1892-1897), organizou um torneio medieval em Kelburn Castle, na Escócia, onde todos os participantes tiveram que estar trajados à época.

\footnotetext{
${ }^{4}$ BerEns, Daniel J, WWII Reenactment in west-central Wisconsin: context of history and memory from the last world war Eau Claire, Wiscosin MAY 2008. http://minds.wisconsin. edu/bitstream/handle/1793/28790/BerensSpring08.pdf?sequence=2.Acesso em 10 de julho de 2009.

5 GILES, Howard, "Recreating the Past for Live Events, TV, and Film: A Brief History of Reenactment. http://www.eventplan.co.uk/history_of_reenactment.htm. Acesso em $10 \mathrm{de}$ julho de 2009.
} 
Este episódio poderia ser visto como um precursor de uma moderna Feira Medieval ou do Renascimento, outra forma de história ao vivo e de reconstituição histórica.

Em Fevereiro de 1895, cerca de cem membros do grupo Gloucestershire Engineer Volunteers recriou a famosa batalha da defesa de Rorkes Drift em Natal. Setenta e cinco elementos estavam vestidos de "Zulus", enquanto os outros vinte e cinco estavam trajados como "redcoats" (armada britânica).

No entanto, estes tipos de eventos/batalhas não se limitaram às ilhas britânicas. Em 1876, os sobreviventes do Custer's Last Stand at Little Big Horn foram encorajados a regressar ao campo de batalha e recriar os acontecimentos da batalha para os fotógrafos. Durante o século XIX e início do século $\mathrm{XX}$, membros de diferentes organizações começaram a homenagear os pais e os avós que foram soldados e morreram na Guerra Civil Americana.

\section{Living History - História ao Vivo em Portugal}

A "História ao Vivo" (Living History), começou a dar os seus primeiros passos em Portugal, a partir da década de 80 do século XX, depois de ser implementado com grande sucesso em Inglaterra graças à ação do Departamento "The Historic Buildings and Monuments Comission for England» em 1979, que promoveu dois programas para as escolas de Suffolk: o projeto de reconstituição de Havening Hall, mansão do século XVIII, da época georgiana (bem conservada), no interior de SuffolK, onde uma multidão de criados serve o proprietário e a sua família; seguindo-se-lhe o projeto do Castelo de Oxford (quase em ruínas), situado no litoral do mesmo condado, que em 1173 tem à sua volta um enxame de artesãos que o vai "construir».

Os projetos de Living History, orientados por Patrick Redsell, tiveram impato também no Brasil, tendo sido esta técnica posta à prova em Massangana - «Um dia no engenho».

Em Portugal, a Associação Portuguesa de Museologia - APOM, conhecedora destes projetos de Living History, e apoiada pelo Instituto Britânico 
em Portugal, convidou os técnicos ingleses Patrik Redsell (dramaturgo), Stephen Wolfendem (fotógrafo) e Michael Corbishey (pedagogo), e ainda a conservadora brasileira Lurdes Horta Barreto para participarem no Colóquio APOM de 1986, que teve lugar em Faro ${ }^{6}$.

O estudo, a investigação, o aprofundamento, a experimentação prática e a aprendizagem de antigas técnicas são em suma as palavras de referência de quem deseja aproximar-se da "Recriação Histórica".

Fazer "história ao vivo" significa dar rosto, forma, realismo e uma alma a aos personagens cuja vida quotidiana se tenta recriar; o que só é possível graças a uma séria e documentada ação de reconstrução que deve, obrigatoriamente, levar em conta em primeiro lugar a autenticidade: autenticidade do vestuário em cada caso, autenticidade na preparação de ambientes e situações que se tentam mostrar ao público, autenticidade em ressuscitar o espírito de uma época já passada.

Vestir, atuar, sentir e chegar inclusivamente, se não a pensar, pelo menos a identificar-se com um mercador do Ano 1000, um cavaleiro de 1200, uma camponesa do século XIV, uma mulber nobre do Renascimento, um soldado da Primeira Guerra Mundial, um partisan da Segunda Guerra Mundial: todos eles, em conjunto são uma "Recriação Histórica".

Dar-se um nome, construir em torno daquele nome um personagem com uma história bem definida vivendo-a como se efetivamente fosse a sua própria história, também isso é Recriação Histórica ${ }^{7}$.

$\mathrm{E}$ assim desejosos de um regresso ao passado, às etapas que marcaram a humanidade, os apaixonados da história ao vivo encontram-se, produzem os seus próprios trajes e sapatos, dormem em tendas sobre fardos de palha, comem alimentos cozinhados com estranhos procedimentos, animam acampamentos, praças e cidades.

\footnotetext{
6 Solé, Maria Glória Parra Santos, "A técnica de história ao vivo - a realização de uma feira medieval no Lindoso" (Didáticas e Metodologias de Ensino) Instituto de Estudos da Criança- Universidade do Minho. Comunicação apresentada no IV Encontro Nacional de Didáticas e Metodologias da Educação - "Percursos e Desafios", Évora, 26-28 set. 2001.

7 Romero, Mabel Villagra. Actualidad del Asociacionismo Recreacionista en Europa: el caso italiano.

2. ${ }^{\circ}$ Encuentro de Grupos de Recreación Histórica Medieval de Aragón, Alcañiz (Teruel). 2006.
} 


\section{O boom das feiras medievais}

As recriações históricas em Portugal, nomeadamente as feiras medievais, registaram nos últimos anos "um "boom", que trouxe "óbvias vantagens" para quem trabalha na área, mas que tem redundado também numa maior falta de rigor histórico.

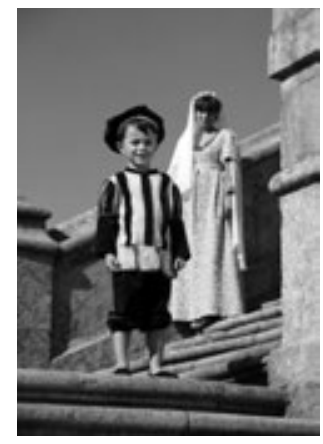

FIG. 2. Arquivo Federação das Coletividades de Cultura e Recreio de Santa Maria da Feira

Neste sentido deixamos as seguintes questões para as quais, procuraremos respostas.

Quando uma Câmara Municipal, uma Junta de Freguesia, uma Empresa Municipal organiza um evento com fundamento e contexto histórico, para além de procurar, com toda a legitimidade, arrastar multidões e obter rentabilidade económica, passar testemunhos de vitalidade e de intervenção, poderá satisfazer-se apenas com a festa propriamente dita?

Não será por demais redutor o contentamento proveniente de um convívio, numa espécie de hiato no quotidiano, de fácil estímulo, com os "comes e bebes" à mistura com sons e cheiros, e na maior parte das vezes uma feira de "artes e ofícios de época" - tudo ao serviço de um imaginário de outros tempos?

Calcula-se que em 2010 se tenham realizado em Portugal mais de 120 Feiras Medievais e Quinhentistas de média ou grande dimensão, e pelo menos outras tantas recriações de outras épocas históricas. 


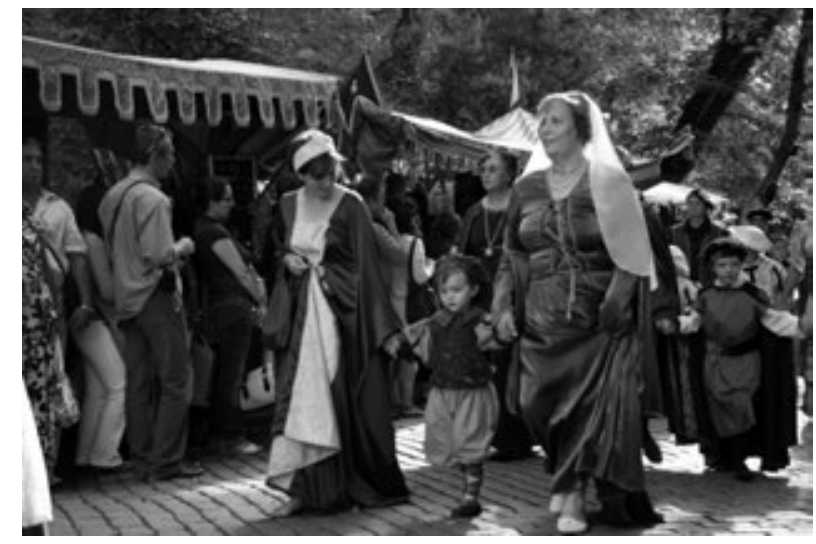

FIG. 3. Foto Albino Santos, Jornal Correio da Feira

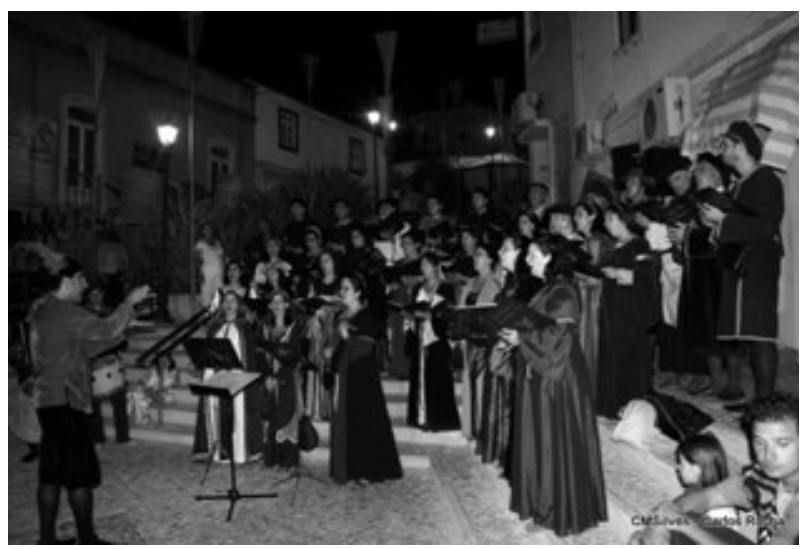

FIG. 4. Feira Medieval de Silves, Foto Carlos Rocha

Algumas estão firmemente implantadas, e são já ex-líbris locais. A Feira Medieval de Coimbra (com uma peculiar ligação a grupos amadores, associada ao melhor rigor histórico que encontramos em Portugal), a Viagem Medieval de Santa Maria da Feira (enraizada nas coletividades locais e que se destaca pela sua dimensão, sendo considerada a maior que se realiza em Portugal), os Dias Medievais de Castro Marim, a Feira Medieval de Silves cada vez mais vocacionada para a recriação da época moura, e o Mercado Medieval de Óbidos. 


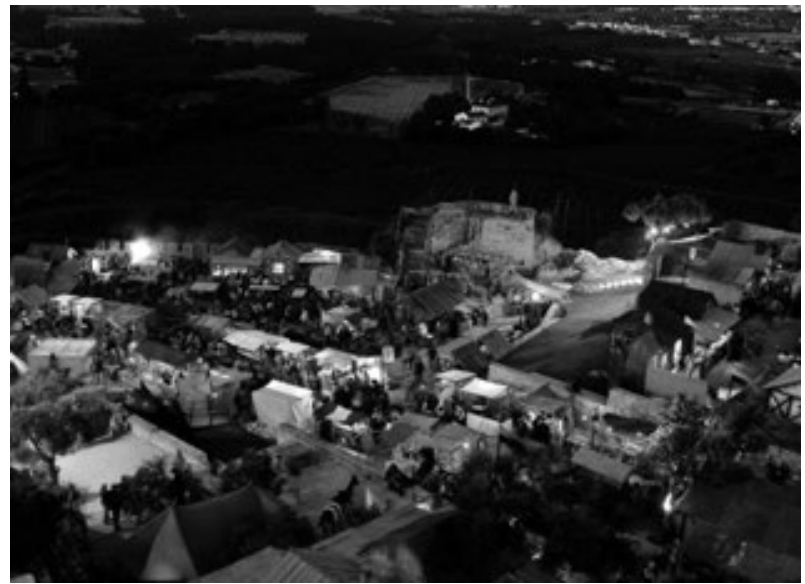

FIG. 5. Mercado Medieval de Óbidos. Arquivo Câmara Municipal de Óbidos

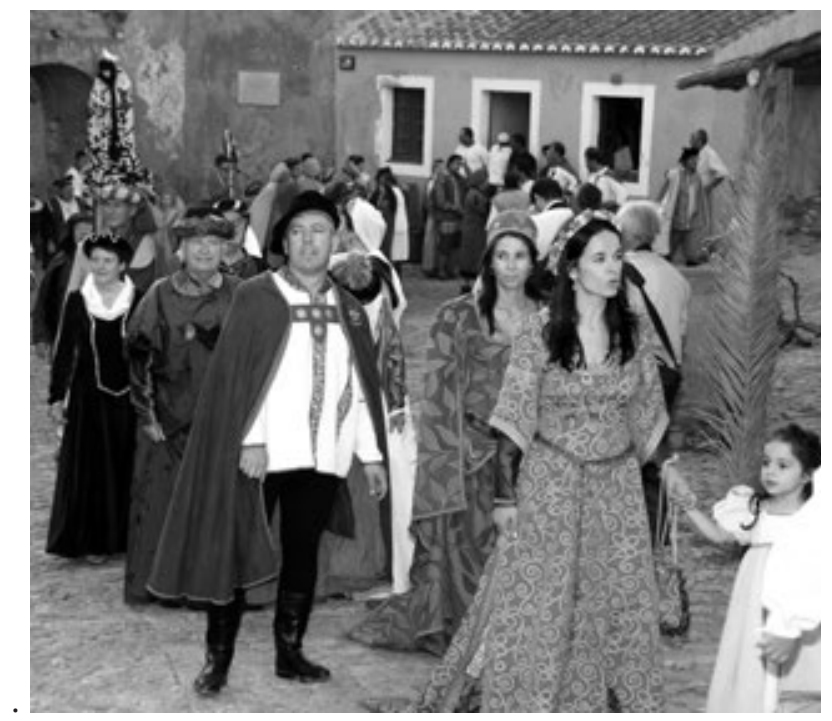

FIG. 6. Dias Medievais Castro Marim.

Arquivo Câmara Municipal de Casto Marim

A estes exemplos acrescentam-se outras recriações e de outras épocas. Todavia, tomamos como "case sudy", o evento que se realiza em Santa Maria da Feira, a Viagem Medieval em Terras de Santa Maria. 


\section{Recriações Históricas - O Caso de Santa Maria da Feira}

O evento Viagem Medieval em Terra de Santa Maria que se organiza em Santa Maria da Feira é um extraordinário exemplo de projeto de rentabilização dos recursos patrimoniais através daquilo que Jesús Pena Castro designa no seu trabalho El negocio de la historia en la Feria Medieval de Noia, “como sendo o mercado da história, das suas narrativas e dos espaços, bem como os níveis de autenticidade vividos e apreciados na recriação."

Para obtermos uma informação mais completa sobre o caso de Santa Maria da Feira, procuramos aferir sobre as possibilidades de aproveitamento deste evento cultural de Santa Maria da Feira para a construção de novos roteiros turísticos temáticos, a fim de incrementar a atividade turística na cidade. Neste sentido, foram elaboradas entrevistas abertas a visitantes (384), a participantes (278) e a residentes (383), com a relação da dimensão da população com a amostra (tabela a 95 \%) e o erro aceite em desvio-padrão é de 0,1$)$.

Pela análise dos primeiros elementos, quanto à opinião dos residentes, dos visitantes e dos participantes a respeito do evento, devemos assinalar que se alterou radicalmente em comparação ao que aconteceu na primeira edição. O rotundo sucesso económico e o orgulho que a recriação medieval gerou, favoreceram enormemente o crescimento da opinião positiva.

Consideramos que com este estudo, poderá haver claramente uma reflexão sobre as relações que podem ser estabelecidas entre o Turismo, o Património Cultural, o Planeamento, a Preservação e Desenvolvimento Económico.

Destacaremos então a recriação histórica, a requalificação urbana, os seus impatos em termos económicos e a possibilidade da estruturação de um parque, uma vez que o Turismo é uma das atividades que atualmente ajuda à obtenção de resultados relevantes no que concerne à preservação da memória e identidade, ao apresentar aos turistas e/ou visitantes a essência e os significados do património local.

Mas, se de fato o turismo gera desenvolvimento, trata-se, no entanto, de "uma atividade que depende largamente das conjunturas económicas o que introduz um caráter de vulnerabilidade que não pode deixar de 
ser sempre considerado. Da circunstância do setor do turismo interferir e depender de outros subsetores, como a construção civil, o comércio, os transportes, leva a que qualquer oscilação operada se reflita, de imediato, em importantes setores da atividade económica.

O seu efeito multiplicador pode, assim, funcionar como importante acelerador de desenvolvimento mas pode também permitir que situações de crise se expandam mais rapidamente a outros setores produtivos" .

“ $A$ atividade turística em Portugal, apesar de constituir um fenómeno relativamente recente enquanto atividade económica organizada apresenta uma já considerável diversificação e segmentação, ainda que continue a assentar fortemente no chamado turismo balnear litoral ou turismo de sol e mar. Este é, de fato, o setor mais massificado, aquele que mais nacionais faz deslocar dentro do país e que maior número de estrangeiros atrai, sendo, portanto, o setor de mercado turístico de maior significado económico e de maior relevância geográfica, quer pela importância de que se reveste na mobilidade da população, quer pelo papel que desempenha na transformação dos espaços e da paisagem, quer, ainda, pelos impates ambientais e sociais que gera" 9 .

Ao analisarmos a trajetória de Santa Maria da Feira, a partir da segunda metade do século XX, percebe-se claramente a mudança de uma economia fortemente assente na indústria, para atividades económicas do setor terciário que envolve a prestação de serviços, o comércio, o turismo entre outros.

Na década de 90, a Câmara Municipal de Santa Maria da Feira procurou estimular a atração de empresas hoteleiras de grande dimensão, que foi mais ou menos bem conseguida, nomeadamente devido à construção do Europarque.

Contudo, neste mesmo período, através da aposta num Plano para o Turismo, abriram-se novas perspetivas para o Município. Tal iniciativa teve como objetivo transformar a cidade num destino turístico regional e nacio-

\footnotetext{
8 Cravidão, Fernanda. Turismo e Desenvolvimento - o distrito de Coimbra, 1980-1987, separata de Arunce, Lousã.1989.

9 Cunha, Lúcio. Turismo e desenvolvimento na Raia Central. Cadernos de Geografia, 14, Coimbra, FLUC, pp. 129-138. 1995.
} 
nal, e consequentemente, gerar receitas e postos de trabalho. O Município apostou numa série de ações, visando a mobilização da comunidade, dos empresários, bem como das escolas e particulares, para torná-los atores conscientes do seu papel na implantação da atividade turística.

Ainda neste sentido, fruto da ação da Câmara Municipal, e da Associação Empresarial de Portugal foi construído o primeiro centro de congressos do Concelho, o Europarque, com objetivo de responder às necessidades do Turismo de Eventos e de Negócios da cidade e da região. A finalidade foi incrementar o fluxo de turistas e aumentar as oportunidades de empregos diretos e indiretos. Um dos grandes eventos foi a Presidência da União Europeia em 2000. Foram construídos novos hotéis e outros estavam projetados, exigindo mão-de-obra qualificada para que possam assegurar ao turista a excelência de atendimento, apesar do abrandamento do investimento motivado pela crise económica atual.

Em 1999, a Câmara Municipal criou a Sociedade de Turismo de Santa Maria da Feira, S.A, uma entidade de capitais mistos que tem como fundamento conciliar interesses públicos e privados com o objetivo de rentabilizar esforços em prol do Turismo da região.

A sua missão assentava na definição e promoção de estratégias de desenvolvimento turístico no concelho de Santa Maria da Feira, bem como a gestão dos recursos e equipamentos do âmbito turístico, nomeadamente a exploração da água mineral e da atividade termal das Termas de S. Jorge e a organização de eventos com temática medieval, das quais se salienta o produto turístico já consolidado apesar da conjuntura atual (Ceias Medievais), vocacionado para a área do Turismo de Negócios e Incentivos.

Além disto, e fruto da delegação de competências relacionadas com a atividade cultural da Câmara Municipal na Empresa Municipal Feira Viva e o estabelecimento de parcerias com o tecido associativo concelhio e outras entidades, o Concelho continuou a potenciar os eventos como a Viagem Medieval em Terra de Santa Maria, o Festival da Juventude, o Festival de Cinema Luso-Brasileiro, o Festival para Gente Sentada, o Rock VFR/Rocktaract e o Imaginarius - Festival Internacional de Teatro de Rua, Semana Santa, as Invasões Francesas, a Festa das Fogaceiras entre outros, tornaram Santa Maria da Feira um palco de experiências por excelência, 
aumentando, por sua vez, a movimentação nos hotéis, bares e restaurantes, comércio e transportes públicos.

Pelas transformações que Santa Maria da Feira vive atualmente e apesar da grave crise económica, que se traduz no aumento do desemprego e da emigração, é preciso salientar que não se acredita que a cidade fique parada no tempo, pois o dinamismo é inerente ao processo histórico, à memória e à cultura dos locais.

O conceito lugar de memória está mais vinculado às análises sobre a preservação e o património. No turismo a sua melhor integração seria como "conceção que remete diretamente à afetividade, integridade e identidades locais"10.

Segundo Huyssen, "a emergência da memória é um dos fenómenos culturais e políticos mais caraterísticos dos fins do século X., devido à transformação que ocorreu na sociedade, nomeadamente a mudança em relação à perceção do tempo de futuro-presente para passado-presente". ${ }^{11}$

\section{Viagem Medieval em Terras de Santa Maria}

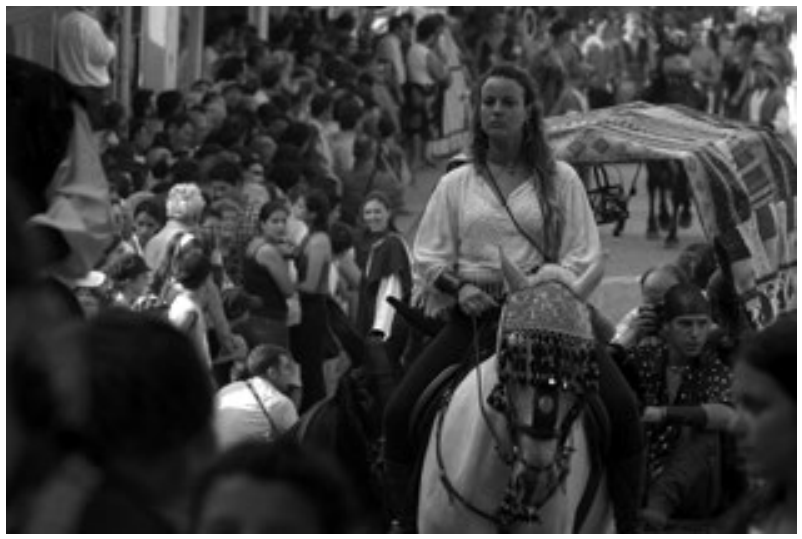

FIG. 7. Viagem Medieval em Terra de Santa Maria. Foto Arquivo Viagem Medieval em Terra de Santa Maria

\footnotetext{
10 GASTAL, Susana. "Lugar de memória: por uma nova aproximação teórica ao património local”. In: Gastal. S. (org.). Turismo investigação e crítica. São Paulo: Contexto, p. 69-81. 2002.

11 Huyssen, Andréas. Seduzidos pela memória. Rio de Janeiro: Aeroplano, 2000.
} 
Como já verificamos, "a realização de Feiras Medievais é já um bábito em muitas localidades com história que lhes permitem recriar os ambientes da época em causa. No entanto, umas destacam-se pela qualidade da produção, preocupada com os mais pequenos detalbes, que atraem cada vez mais interessados num evento de qualidade, enquanto outras realizam-se com padrões de recriação da época que deixam muito a desejar e que, por vezes, levam a questionar a realização do evento, tão pequena a sua dimensão e tão rudimentar a produção"12.

No cenário nacional, a Viagem Medieval em Terra de Santa Maria, realizada em Santa Maria da Feira, é sem dúvida uma das melhores, se não mesmo a melhor. Uma visita rápida ao site do evento (http://www. viagemmedieval.com) permite-nos perceber o que a distingue de todos os outros eventos semelhantes, como Óbidos, Castro Marim ou mesmo Silves.

A Viagem Medieval começou com uma pequena feira dentro das muralhas do castelo, em 1996, sob proposta de duas finalistas do Curso de Turismo. Prosseguiu em 1997, durante dois dias em Setembro com a interrupção em 1998. Em 1999 a Federação das Coletividades de Cultura e Recreio, juntamente com a Câmara Municipal de Santa Maria da Feira e a Escola Fernando Pessoa chamou a si a organização do evento, realizando-se o primeiro grande cortejo com a participação de 400 figurantes. Esta edição já decorreu durante 3 dias no mês de Junho, também dentro das muralhas do Castelo. O salto qualitativo decorreu em 2000, coincidindo com a presidência portuguesa da União Europeia cuja cimeira dos Chefes de estado decorreu no Europarque.

A Câmara Municipal envolveu-se na organização da Viagem Medieval, constituindo-se no grande parceiro da Federação das Coletividades de Cultura e de Recreio de Santa Maria da Feira. O evento alargou-se por toda a cidade e o número de dias aumentou para 11, decorrendo entre 10 e 20 de Junho.

12 Carlos, Roberto ; DIAS, Francisco de Almeida, 1957-, fotogr. Viagem Medieval em Terra de Santa Maria. 2002 


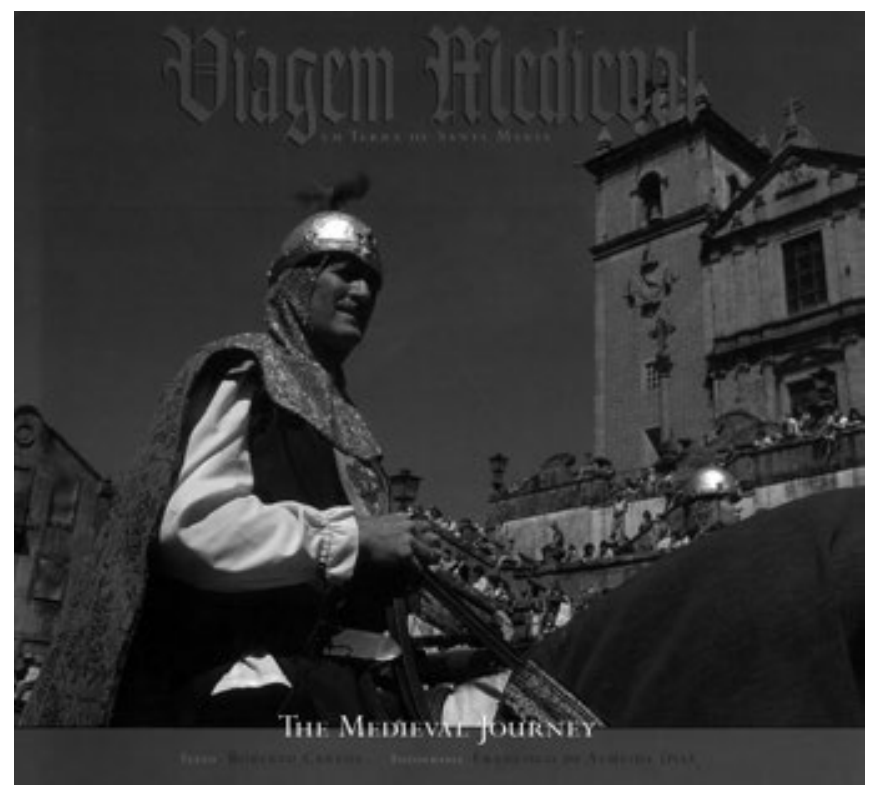

FIG. 8. Capa do livro Viagem Medieval em Terra de Santa Maria - The Medieval Journey, publicado em 2002.

Texto de Roberto Carlos e Fotografia de Francisco de Almeida Dias

Outra mudança verificou-se no ano de 2003, quando o evento passou a ser realizado em Agosto, permitindo um grande afluxo de veraneantes, turistas e emigrantes.

Em 2005, o início da Viagem Medieval em Terra de Santa Maria passou a coincidir com última sexta-feira de Julho, porém na edição de 2009 passou a iniciar-se na última quinta-feira do mesmo mês, decorrendo sempre até ao primeiro domingo de Agosto.

Em 2010 uma das principais inovações foi o Campo de Tendilhas que decorreu na (Quinta do Castelo) dinamizado pelo Agrupamento 640 do Corpo Nacional de Escutas, permitindo desde então o alojamento em ambiente medieval.

Em termos de números salienta-se que nesta edição a Organização integrou 72 elementos; a Animação 490 elementos; os grupos de animação circulante foram 36; envolveram-se 41 associações do concelho; candidataram-se 608 voluntários para serem selecionados 230 para as 
diferentes áreas do projeto. Na feira franca participaram 248 cidadãos, 180 portugueses e 68 estrangeiros, dos quais 101 artesãos, 16 artífices, 57 mercadores e 74 regatões. A animação durante o evento totalizou 135 horas e trabalharam em 2010 na Viagem Medieval 1100 pessoas num perímetro de 33 hetares, ou seja ao longo de 330 mil metros quadrados. O orçamento do evento de 2010 foi de $750 \mathrm{mil} \mathrm{euros,} \mathrm{gerando} 550 \mathrm{mil}$ Euros de receita. O apoio da Câmara Municipal foi 200 mil euros.

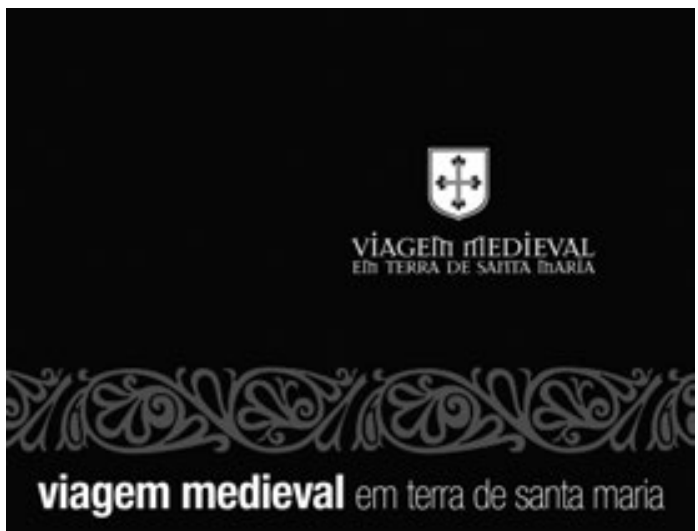

santa maria da feira 01 a 10 agosto '03 muw.viagemmedieval com

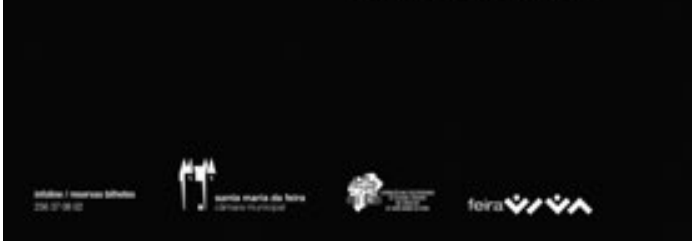

FIG. 9. Cartaz da Viagem Medieval em Terra de Santa Maria de 2003. Arquivo Viagem Medieval em Terra de Santa Maria

Em 2011, houve uma outra alteração profunda visando a sustentabilidade do projeto, ou seja a $15 .^{\text {a }}$ edição do evento teve entrada paga em determinados horários das $17 \mathrm{~h} 00$ às $01 \mathrm{~h} 00$ nos dias úteis e das $12 \mathrm{~h} 00$ 
até à mesma hora aos fins-de-semana - com exceção para os domingos à noite, em que os pórticos de acesso ao recinto encerraram às $23 \mathrm{~h} 45$.

A entrada no perímetro da Viagem Medieval implicou a aquisição e a utilização de uma pulseira (pessoal, intransmissível e inviolável) com um custo de dois euros, permitindo o acesso a dez dias do evento. A entrada foi livre no primeiro dia e as crianças até $1,30 \mathrm{~m}$ de altura não pagavam.

Registaram-se 229 mil entradas pagas no recinto, e com esta inovação ficou garantida a auto-sustentabilidade do evento. A receita das pulseiras cobriu o apoio da Câmara Municipal, que neste ano já não investiu orçamento próprio na Viagem, num orçamento global de 900 mil euros.

Em termos estatísticos a primeira edição paga da Viagem Medieval teve 20 áreas temáticas com atividades, 170 encenações de espetáculos e 1.400 performances de animação circulante, totalizando 135 horas de animação. Tudo isto assegurado por 55 grupos, 35 dos quais de Santa Maria da Feira, onde intervieram 900 pessoas.

$\mathrm{Na}$ feira franca, participaram 220 pessoas, distribuídas por artesãos, artífices, mercadores e regatões. Trabalharam diariamente mais de 2000 pessoas no evento, coordenadas por 75 elementos da Organização, destacando-se também a imprescindível colaboração de 400 voluntários.

O orçamento de 2011 foi 900 mil euros, sendo que 150 mil foram de investimento (pórticos, acessibilidades ao recinto, e estruturas dos restaurantes).

Em 2012, a 16. ${ }^{a}$ edição da Viagem Medieval realizar-se-á de 26 de Julho a 05 de Agosto e vai abordar novamente o século XII, dedicada ao reinado de D. Sancho I. Em 2012 haverá um bilhete de um dia e a pulseira será para quem quiser vir ao recinto todos os dias.

Do estudo de 2009 - Os impatos dos eventos turísticos - o caso da Viagem Medieval em Santa Maria da Feira, de Maria do Rosário Barros de Oliveira, na Dissertação apresentada à Universidade Fernando Pessoa como parte dos requisitos para obtenção do grau de Mestre em Ciências Empresariais, salientamos que os resultados que se apresentam em seguida referem-se a uma amostra da população (315 indivíduos).

Da análise dos resultados apresentados, a "maioria dos inquiridos (35,2\%) tem idades compreendidas entre 15 e 25 anos, $27,9 \%$ entre 26 e 
35 anos, 21\% entre 36 e 45 anos, 12,7\% entre 46 e 55 anos, 2,9\% entre 56 e 65 anos e $0,3 \%$ mais de 65 anos de idade. Conclui-se que a população respondente é jovem com idades compreendidas entre os 15 e os 45 anos de idade.

Dos respondentes, 3,8\% participaram nas tendas de artesanato, 5,1\% no sistema de ordem e segurança do evento, 7,9\% nos grupos de animação cultural e $8,6 \%$ nas tabernas, sendo esta última a que teve maior participação .

A maioria dos inquiridos, $86,4 \%$, considera a Viagem Medieval muito importante, dos quais $23,2 \%$ considera muito importante, $27,6 \%$ considera muitíssimo importante e 35,6\% considera extremamente importante para o desenvolvimento do Concelho. Somente 9,8\% dos respondentes, consideram apenas importante.

Relativamente aos restantes respondentes, $3,8 \%$ consideram nada importante, pouquíssimo importante ou pouco importante, respetivamente, 2,2\%, $0,6 \% \mathrm{e} 1 \%$. Conclui-se portanto, que a grande maioria dos respondentes consideram que o evento é muito importante para o desenvolvimento de Santa Maria da Feira.

Os dados recolhidos referentes à opinião dos inquiridos sobre os impatos económicos, sociais, culturais e ambientais, dizem-nos que em relação aos impatos positivos e, considerando o somatório das opiniões positivas verifica-se que a maioria dos respondentes concorda que o evento atrai mais investimento $(77,5 \%)$.

Dos respondentes, $80,6 \%$ concorda que o evento promove o comércio e indústria locais, $85,4 \%$ concorda que aumenta os meios recreativos e de lazer, $75,6 \%$ que recupera o artesanato e $70,8 \%$ que incentiva a restauração dos edifícios históricos. Em menor percentagem, 56,2\% dos respondentes concorda que o evento cria posto de trabalho.

Apenas $47 \%$ concorda com o fato do evento aumentar a sensibilização e a consciencialização ambiental da comunidade local e $34 \%$ dos inquiridos concorda que a Viagem Medieval proporciona a melhoria das infra-estruturas públicas.

Desta análise conclui-se que os respondentes da amostra da população acreditam que o evento influencia, em primeiro lugar nos impatos 
positivos relacionados com a cultura e património. Em segundo lugar os impatos positivos relacionados com o com o comércio e benefícios económicos. Em terceiro, os impatos positivos relacionados com as questões sociais e em último lugar os impatos positivos relacionados com o meio ambiente. De referir ainda a semelhança entre as respostas de concordância e não concordância sobre o impato do evento nas infra-estruturas públicas.

Quanto aos impatos negativos, destacam-se o aumento do congestionamento e do tráfego com a maior parte das concordâncias positivas, com $83,8 \%$, o aumento dos preços com $61 \%$ das concordâncias positivas e o aumento da poluição ambiental com $47 \%$ das concordâncias positivas.

Sumariamente, o aumento do congestionamento e do tráfego urbano assim como o aumento dos preços são refletidos nas concordâncias dos respondentes como impatos negativos provocados pelo evento. Considera-se também o aumento da poluição ambiental como impato negativo gerado pelo evento, mais identificado pelas entidades respondentes, uma vez que o somatório das percentagens das concordâncias positivas é superior ao somatório das negativas"13.

Outros dos indicadores que poderemos levar em linha de conta tem a ver com o número de visitantes no posto de turismo municipal, que no ano de 2010, os meses que registaram maior adesão foram o de Julho (com 797 visitantes), Agosto (537 visitantes) e Janeiro (471 visitantes). Por sua vez, os meses de Fevereiro (214 visitantes) e Novembro (234 visitantes) foram aqueles que registaram menos visitantes a deslocar-se ao Posto de Turismo. Estes indicadores de procura relacionam-se com as datas de realização da Viagem Medieval.

Relativamente aos dois eventos primordiais da cidade, o Imaginarius - Festival Internacional de Teatro de Rua registou um decréscimo de $33,33 \%$ do número de visitantes, e a Viagem Medieval apesar de no ano de 2010 contar com mais um dia de realização manteve o mesmo número de visitantes.

13 Oliveira, Maria do Rosário Barros. Os impatos dos eventos turísticos - o caso da Viagem Medieval em Santa Maria da Feira. 2009. 


\begin{tabular}{|c|c|c|c|}
\hline $\begin{array}{r}\text { Imaginarius } \\
(\text { Maio })\end{array}$ & 2010 & 2009 & Var. $\%$ \\
\hline (estimativa aprox.) & 2.000 Visitantes em 3 dias & 3.000 Visitantes em 4 dias & $-33,33 \%$ \\
\hline $\begin{array}{r}\text { Viagem Medieval } \\
\text { (Agosto) }\end{array}$ & 2010 & 2009 & Var.\% \\
\hline (estimativa aprox.) & 4.000 Visitantes em 11 dias & 4.000 Visitantes em 10 dias & $\mathbf{0 , 0 0} \%$ \\
\hline
\end{tabular}

Relativamente à origem dos turistas e visitantes que se deslocaram ao Posto de Turismo Municipal no ano de 2010, foram, na sua grande maioria, provenientes de território nacional $(88,71 \%)$. No que diz respeito aos visitantes internacionais, que registaram um importante acréscimo de 127,4 \%, são maioritariamente provenientes da Espanha (40,3\%), França $(28,2 \%)$, Brasil $(10,9 \%)$ e Inglaterra $(7,1 \%)$.

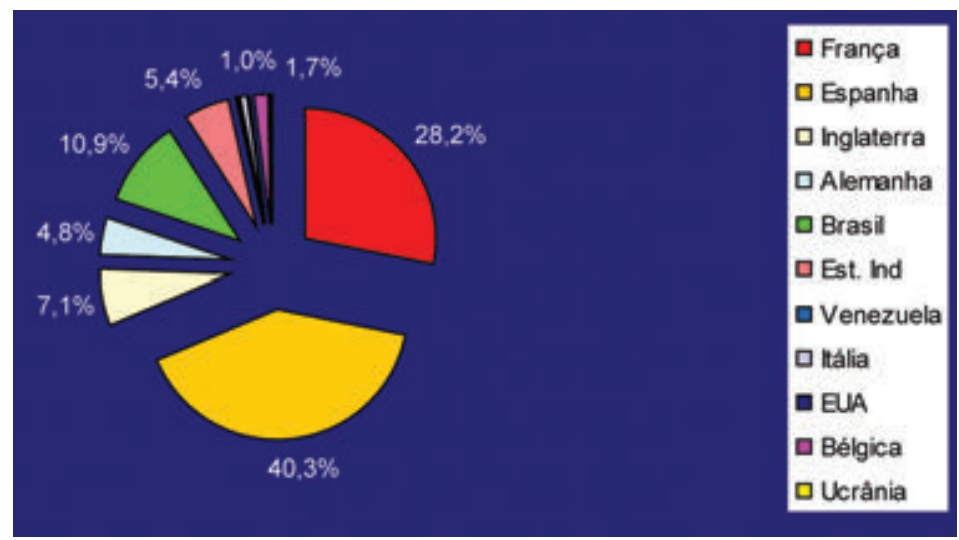

Analisando também as dormidas de turistas nas unidades de alojamento de Santa Maria da Feira que disponibilizaram dados estatísticos, verifica-se que no ano de 2010 registou-se um ligeiro acréscimo de 5,4\%. Sendo que o hotel íbis contribui em grande escala para isso visto ter aumentado o número de dormidas em mais de $40 \%$. Os meses de julho e agosto, coincidentes com a Viagem Medieval são aqueles que mais procura de alojamento têm. 


\begin{tabular}{|c|c|c|c|c|c|}
\hline \multirow{2}{*}{} & \multicolumn{5}{|c|}{ Dormidas de turistas 2010 } \\
\cline { 2 - 6 } & Totais & Nacionais & Estrangeiros & 2009 & Var.\% \\
\hline Hotel Nova Cruz & $\mathbf{1 3 . 7 1 1}$ & 10.111 & 3.600 & $\mathbf{1 3 . 2 2 3}$ & $3,7 \%$ \\
\hline Hotel Pedra Bela & $\mathbf{1 0 . 9 6 3}$ & 7.045 & 3.918 & $\mathbf{1 3 . 1 7 3}$ & $-16,8 \%$ \\
\hline Hotel Lóios & $\mathbf{7 . 7 5 5}$ & 5.051 & 2.704 & $\mathbf{8 . 4 6 9}$ & $-8,4 \%$ \\
\hline Hotel Íbis & $\mathbf{1 8 . 6 3 4}$ & & & $\mathbf{1 3 . 2 6 9}$ & $40,4 \%$ \\
\hline Inatel & $\mathbf{6 . 0 7 5}$ & 5.960 & 115 & $\mathbf{6 . 4 2 1}$ & $-5,4 \%$ \\
\hline Pensão São Jorge & $\mathbf{1 . 9 9 9}$ & 1.944 & 55 & $\mathbf{1 . 5 5 6}$ & $28,5 \%$ \\
\hline Total & $\mathbf{5 9 . 1 3 7}$ & $\mathbf{3 0 . 1 1 1}$ & $\mathbf{1 0 . 3 9 2}$ & $\mathbf{5 6 . 1 1 1}$ & $5,4 \%$ \\
\hline
\end{tabular}

Os equipamentos turísticos de Santa Maria da Feira registaram um total de 101.983 visitantes no ano de 2010 (excluindo o Visionarium - Centro de Ciência do Europarque), o que reflete um crescimento de 1,45\% relativo ao mesmo período do ano anterior, destacando-se o contributo do Castelo (mais 17,7\%) e do Museu do Papel (32,95\%). Refira-se que os meses com maior número de visitantes, foram os de Agosto (13.648), Junho (13.385) e Maio (13.106).

Esta afluência às atrações turísticas também coincide com a realização da Viagem Medieval.

Perante os resultados obtidos em Santa maria da Feira e comparando-os com os efetuados noutros eventos (Dias Medievais de Castro Marim, Feira Medieval de Silves e Mercado Medieval de Óbidos, temos nestes quatro eventos:

- Impatos económicos positivos: criação de emprego; construção de equipamentos; aumento dos níveis culturais e profissionais; modificação positiva da estrutura económica e social; atração de mão-de-obra de outras localidades; incrementa a produção de bens e serviços; aumenta o consumo pelos produtos locais (dos agrícolas ao artesanato); Investimentos estrangeiros; Aumento da cobrança de impostos.

- Impatos económicos negativos: sazonalidade turística; inflação e especulação imobiliária; dependência excessiva de capital investidor estrangeiro; grande parte das divisas sai do país (lucro das multina- 
cionais); dependência excessiva do turismo; mão-de-obra desqualificada na área; aumento do subemprego (ex.: vendedores ambulantes).

- Impatos Sociais Positivos: melhoria da qualidade de vida da comunidade local (criação de infra-estruturas, saúde,..); experiências com os visitantes (culturas e modos de vida diferentes); utilização da população local como mão de obra direta ou indireta. aumento dos níveis culturais e profissionais da população e orgulho étnico.

- Impatos Sociais Negativos: alienação da comunidade local; nativos adotam caraterísticas de vida dos turistas em detrimento dos seus; aparecimento de fenómenos de disfunção social na família (desintegração. da comunidade); marginalidade e prostituição; economia local sensível às consequências do turismo.

- Impatos culturais positivos: preservação e a reabilitação de monumentos, edifícios e locais históricos. valorização da herança cultural - revitalização dos costumes locais como o artesanato, gastronomia. - Impatos culturais negativos: diferenças sociais entre visitantes e moradores (aparecimentos de "guetos" luxuosos; aumento de crime, prostituição, jogo, drogas). descaraterização da cultura do lugar. - Impatos ambientais positivos: revalorização do meio natural (conservação e melhoria qual. ambiental. adoção de medidas para preservar o meio ambiente (parques nacionais). restauração/preservação edifícios/lugares históricos maior envolvimento da administração (introdução de iniciativas de planeamento ambiental). maior envolvimento da população (consciencialização ecológica/ambiental); promove a descoberta e acessibilidade a regiões não exploradas.

- Impatos ambientais negativos: arquitetura e urbanismo desmesurado e/ou não integrados na paisagem. aumento poluição (ruído, ar, água, solo) aumento/congestionamento do tráfego. rivalidade na utilização dos recursos naturais (a competição entre turismo e outras atividades económicas. destruição da paisagem natural, fauna e flora. degradação da paisagem, de sítios históricos e de monumentos". ${ }^{14}$

14 Oliveira, Maria do Rosário Barros; Salazar, Ana Maria. Os impatos do turismo: o caso da Viagem Medieval de Santa Maria da feira 
Como temos vindo a verificar a Viagem Medieval em Terra de Santa Maria é um dos maiores eventos de recriação medieval da Europa e realiza-se anualmente, no centro histórico da cidade de Santa Maria da Feira, atraindo diariamente cerca de 50 mil visitantes.

O projeto apresenta caraterísticas únicas no país, porque se diferencia pelo rigor histórico, dimensão (espacial e temporal), envolvimento da população e associativismo local, reforçando a sua identidade e sentimento de pertença. É centrada na recriação de episódios e acontecimentos que marcaram a história local e nacional na Idade Média.

Pelos momentos de recriação histórica, diversidade de áreas temáticas e qualidade da animação permanente, a Viagem Medieval é um evento de grande envergadura, constituindo uma oferta turística única que potencia a promoção do Município e de toda a Grande Área Metropolitana do Porto.

A Viagem Medieval já foi distinguida com uma menção honrosa na terceira edição dos Prémios Turismo de Portugal (categoria Animação) e arrecadou o prémio Melhor Evento Cultural 2009, na terceira edição da Gala dos Eventos.

Analisando a Viagem Medieval realizada em Santa Maria da Feira, facilmente se percebe que este tipo de eventos atrai não apenas turistas, mas também parceiros estratégicos importantes. Este evento realiza-se no centro Histórico de Santa Maria da Feira e no Vale do Cáster, que foram requalificados na sequência da realização de eventos de recriação histórica bem como de outras realizações marcantes.

\section{Requalificação do Centro Histórico de Santa Maria da Feira}

Como já referirmos noutro ponto, as crescentes preocupações no sentido da recuperação, reabilitação e requalificação urbanas alargam os conceitos de património, fomentando o aparecimento duma consciência de "recuperação" em detrimento de "construção nova".

Cada comunidade, tendo em conta a sua memória coletiva e consciente do seu passado, é responsável pela identificação e pela gestão do seu património, pelo que deverá possuir um conhecimento e uma necessidade de cuidar dos seus valores. 
De fato, em Santa Maria da Feira existiam recomendações no Plano Diretor Municipal que, ao serem generalistas, não se compatibilizavam com as intervenções necessárias, e muito menos tinham em conta que o centro histórico é realmente "património construído" e que a sua qualidade reside na autenticidade e verdade construtiva da sua realização. Nele é já possível observar algumas intervenções ou alterações de projeto, pouco cuidadas, que não respeitam o traçado arquitetónico das ruas, originando o aparecimento de elementos díspares e descaraterizadores, que nada enriquecem o Centro Histórico.

Considerando o enquadramento urbanístico e arquitetónico do Centro Histórico, em que sobressai o equilíbrio do conjunto edificado que compõe toda a sua área urbana, bem como as obras de requalificação urbana, no âmbito do PROCOM, levadas a efeito pela Autarquia, tornou-se necessária a definição de princípios orientadores e de estratégias de intervenção que qualifiquem de forma integrada as próximas intervenções.

\section{Projeto de "Ordenamento, Valorização e Requalificação das Margens do Rio Cáster”}

Este projeto surgiu para implementar uma nova filosofia de fruição do espaço público, que assentasse num novo conceito de rua bem como mudar hábitos, fluxos, movimentos, bem como de palco natural para a realização de diversos projetos.

O que foi proposto foi a diminuição da rodovia, bem como os passeios de maior dimensão. O estacionamento manteve-se, mas de forma regulada através de baías perfeitamente definidas. Existe a consciência dos lugares de estacionamento que se perderam, mas pensa-se que os ganhos serão maiores que as perdas ou seja o automóvel perde, mas o peão ganha.

Rebaixaram-se as guias entre o passeio e a rodovia para o mesmo nível, eliminando as barreiras arquitetónicas, permitindo assim o acesso livre a todos, numa zona que concentra a grande parte dos serviços da cidade. Ainda com o objetivo da fácil mobilidade, carateriza-se através de diferentes cores e texturas os espaços. 


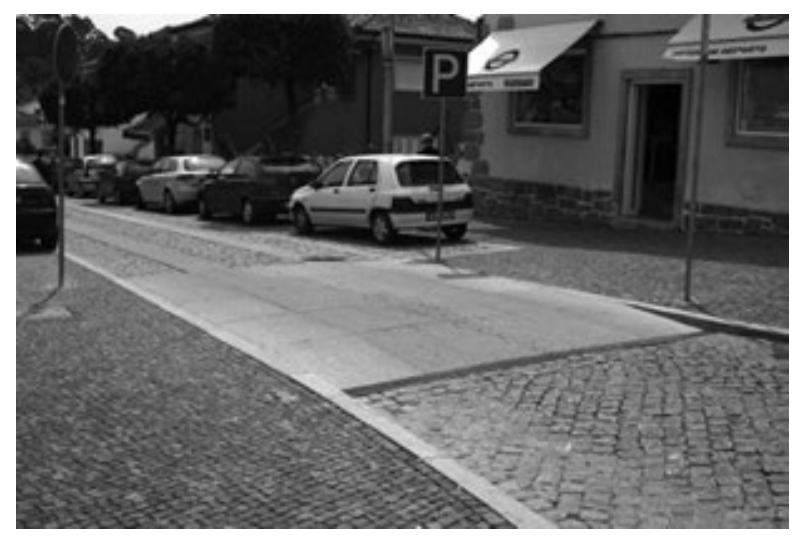

FIg. 10. Rua António Castro Corte Real.

Foto Arquivo Câmara Municipal de Santa Maria da Feira

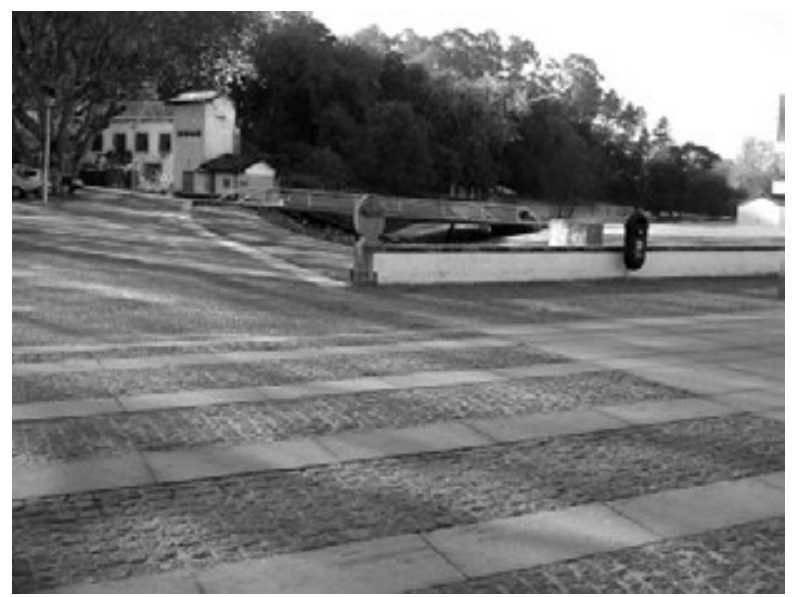

FIG. 11. Rossio.

Foto Arquivo Câmara Municipal de Santa Maria da Feira

\section{Plano de Urbanização do Parque das Guimbras - Vale do Cáster ${ }^{15}$}

O Rio Cáster encaixa-se entre o Castelo de Santa Maria da Feira, com o seu parque de árvores frondosas, e a Baixa da Cidade, onde se destacam

15 Entrevista a Manuel da Costa Lobo, na qual o Responsável pelo Projeto foi explanando as suas ideias de recuperação do Vale do Cáster. 
os largos da Câmara Municipal, da Igreja dos Lóios, a antiga Rua Direita com as suas confeitarias de fogaças, o Rossio ou lugar da feira medieval, o Mercado, da autoria do Arq. Fernando Távora, o "Orfeon", as piscinas, antigos moinhos e um tanque de 1888. Trata-se, enfim, da zona de lazer potencialmente mais notável do centro da Cidade, para a valorização ambiental do espaço urbano.

Analisadas algumas alternativas, a Câmara Municipal de Santa Maria da Feira optou pela construção de um espaço muito qualificado para usufruto da população no Vale do Cáster, ficando também preparado para utilizações temporárias e feiras, como é tradicional.

No edificado em frente ao Rossio, foi efetuada a sua recuperação e a alteração do seu uso, passando a restauração, o mesmo acontecendo ao edifício onde, atualmente, o Rio Cáster se encerra canalizado, localizando-se aí um espaço cultural, designado Casa do Moinho.

$\mathrm{Na}$ área do Rossio (16 700m²) há a possibilidade de usos múltiplos, como a Viagem Medieval e outros acontecimentos.

O Rio Cáster foi sujeito a tratamento, efetuando-se a abertura e limpeza de canal do rio, sendo atravessado com várias pontes de madeira, procurando-se dar unidade ao conjunto.

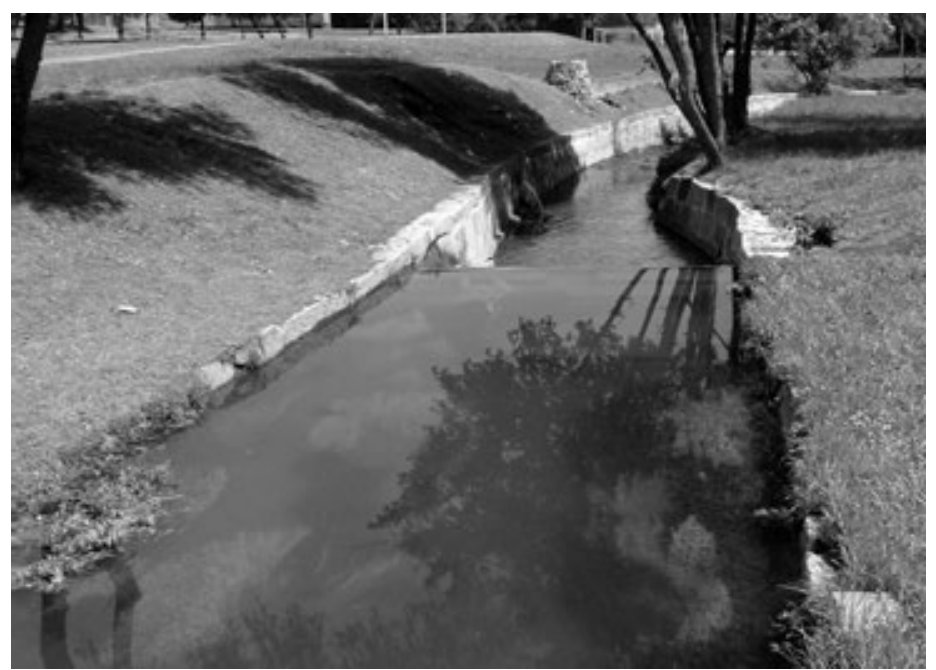

FIG. 12. Rio Cáster. Foto Roberto Carlos 
Pretende-se que seja possível encontrar um local de repouso, contemplação e informação, através da colocação de bancos, bebedouros, cestos de papéis e mapa de indicação da localização e orientação.

Embora estas obras de requalificação venham de encontro ao pensamento exposto no trabalho "Os públicos da cultura de Santa Maria da Feira - Resultados preliminares de uma pesquisa ${ }^{16}$ da autoria de João Teixeira Lopes Bárbara Aibéo, que diz que a "estruturação dos públicos da cultura de Santa Maria da Feira é um processo que assenta num encadeamento de continências. Não se constrói um público num vazio comunicacional ou por mera intencionalidade política. Não existem, ademais, receitas ou cartilhas sociológicas".

Porém nem sempre foi fácil a sua implementação devido a um conjunto de fatores, fatores que não foram muito bem aceites por exemplo pelos comerciantes, numa fase inicial.

Todavia a maioria dos visitantes, reconhece, que este conjunto de obras fez com que a zona do Rossio, o Vale do Cáster em conjunto com o Centro Histórico, se tornasse num espaço de atividade cultura permanente, captando visitantes.

Santa Maria da Feira é efetivamente uma cidade histórica, demarcando-se claramente dos outros Municípios das Terras de Santa Maria.

\section{Impatos económicos}

Pela análise das entrevistas efetuadas, bem como da realização de entrevistas diretas com comerciantes, moradores e participantes, no que diz respeito à rentabilidade económica, a Viagem Medieval constituiu-se num notável sucesso em todas as edições que se celebraram até à data. Durante o período em que a mesma decorre, o Concelho recebe mais de 500 mil visitantes, que gastam uma considerável quantia de dinheiro nas tendas, nas lojas comerciais e nos estabelecimentos hoteleiros. Aparte

16 Comunicação apresentada ao V Congresso Português de Sociologia no Atelier Artes e Culturas. Universidade do Minho. 2004. 
desta rentabilidade imediata, a notória afluência de visitantes supõe uma excelente divulgação do potencial turístico do concelho.

Este evento converteu-se então numa atividade turística lucrativa dentro do programa de promoção do concelho. Paralelamente, ao utilizar como recurso publicitário o passado histórico e os seus vestígios materiais, o evento cumpre a dupla função de demonstrar as possibilidades e a rentabilidade económica dos bens patrimoniais, ao mesmo tempo em que é apresentada como um instrumento de consciencialização sobre a identidade histórica e a importância de se recuperar e conservar os legados da história.

Tem um claro objetivo económico, enquanto se procura multiplicar o número de visitantes e potenciar o comércio, a economia e a hotelaria local mediante a celebração de uma importante atração turística, sendo ao mesmo tempo um instrumento para consciencialização da população sobre as virtudes do património urbano, bem como para fortalecer as raízes de identidade da comunidade nas suas origens históricas.

\section{Santa Maria da Feira e sonho de um parque temático}

A Recriação Histórica como temos vindo a observar é uma área recorrente na dinamização de espaços, além de dar um substancial contributo para o desenvolvimento da iniciativa local, da importância do turismo cultural e da valorização do património monumental.

São várias as tendências identificadas no turismo em todo o mundo, neste caso falamos da tematização do turismo. Porém, quando se fala em tendências, temos que nos lembrar que até a mais dinâmica das economias como a americana, pode ter problemas. Portanto, quaisquer das projeções feitas pela Organização Mundial do Turismo (OMT/UNWTO ou por qualquer outro organismo é passível de mudanças drásticas. As projeções são indicadores de tendências, nem sempre concretizadas na prática e descrevem caminhos para o longo prazo, que poderão ser interrompidos em curto prazo. 
Por tematização, entende-se o uso de um ou mais temas específicos em negócios ou empreendimentos, aliados à fantasia. Num empreendimento temático, tudo deve fazer alusão ao tema ou temas adotados, desde a decoração até ao fardamento dos funcionários, os menus, as atrações, enfim, o objetivo principal é transmitir a sensação que se está num mundo diferente do quotidiano normal.

O turismo apropriou-se da tematização em vários segmentos. Temos em todo o mundo, dezenas de exemplos de negócios bem-sucedidos baseados em temas, que anualmente recebem milhares de turistas ou visitantes, e que levaram crescimento e desenvolvimento a muitas regiões. Entre os segmentos que mais se utilizam da tematização podemos citar os bares, restaurantes, hotelaria e parques.

\section{O Parque Temático das Terras de Santa Maria da Feira}

Em Portugal existem apenas 5 parques temáticos históricos: Portugal dos Pequenitos; Fábrica do Inglês; Parque Mineiro Cova dos Mouros; Parque Temático da Madeira e o Centro de Interpretação da Batalha de Aljubarrota. Os quatros primeiros não têm caraterísticas totalmente históricas. Todos eles são transversais a outras tipologias. Mas isso também é uma caraterística dos parques temáticos históricos que tem o património imaterial na sua génese.

Os parques temáticos constituem um elemento importante para o turismo pois transformam-se em verdadeiros recursos que permitem construir a vocação turística de uma zona ou região, regenerar os destinos turísticos tradicionais e melhorar a sua competitividade. Em Portugal, esta indústria ainda não se encontra muito desenvolvida, pelo que se propõe uma pequena reflexão tendo em vista a criação de um Parque de natureza histórica.

A criação de um parque alusivo às diferentes épocas da História de Portugal nas Terras de Santa Maria, poderá recriar o estilo de vida de diferentes épocas: atividades desenvolvidas; tipo de vestuário; objetos; alimentação entre outros. 
Esta estrutura, para além de vir a constituir uma atração turística para a cidade, teria igualmente como função ser um espaço de formação aberto à comunidade e de um modo especial à comunidade educativa.
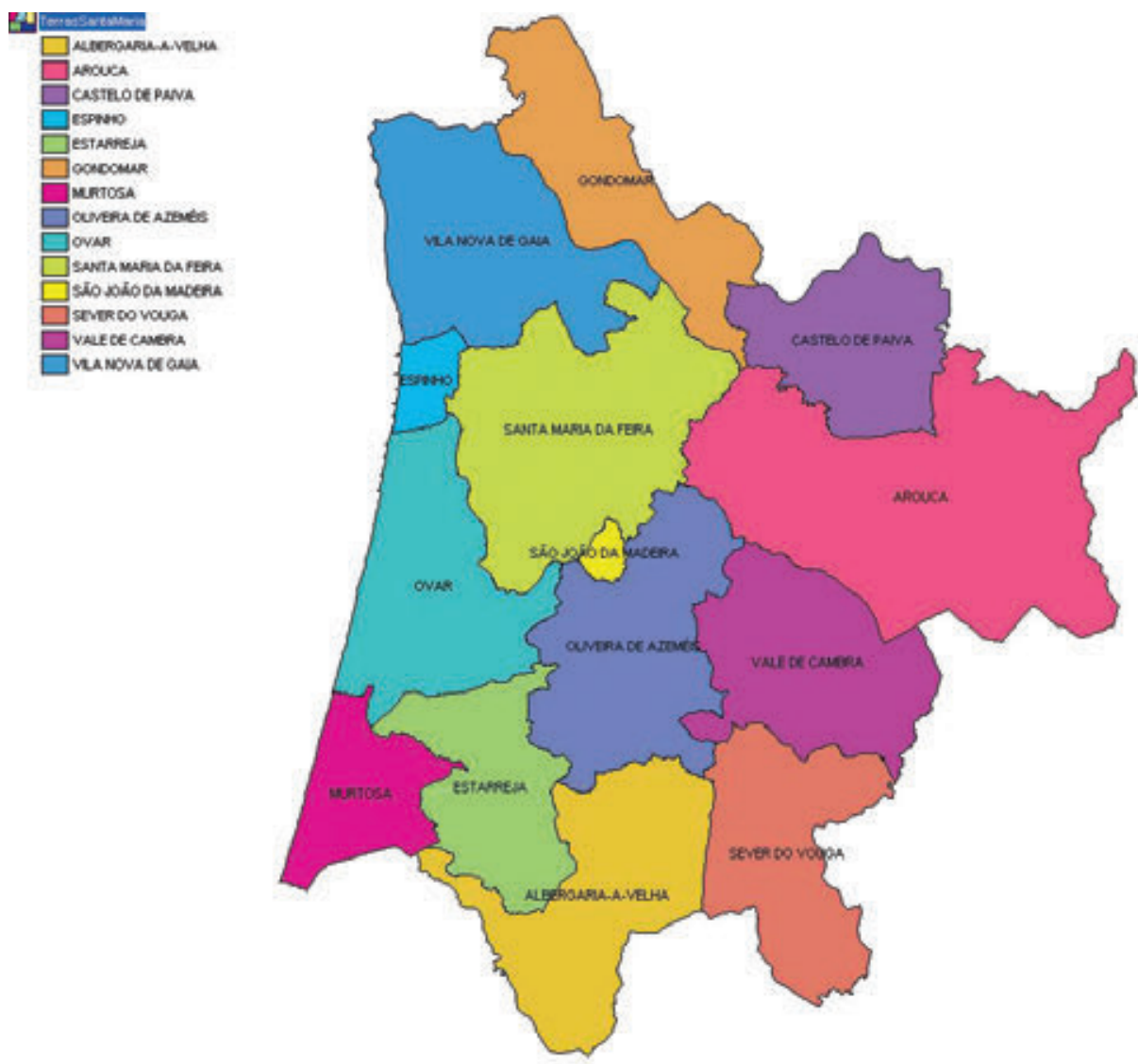

FIG. 13. Mapa com a identificação das Terras de Santa Maria. SIG Câmara Municipal de Santa Maria da Feira

Paralelamente, e uma vez que nos Concelhos das Terras de Santa Maria da Feira são já realizados outros eventos de recriação histórica (Arouca, Uma Recriação Histórica Espinho - Vir a Banhos. Recriação de uma praia do início do século XX; Gondomar - A recriação histórica da Assinatura da Convenção de Gramido; Murtosa - Reconstituição do Ciclo do Milho; 
Oliveira de Azeméis. Era Uma vez, Mercado à Moda à Antiga; Santa Maria da Feira: Viagem Medieval, Festa das Fogaceiras, Via-Sacra, Invasões Francesas, Centenário Vale do Vouga, Centenário da República; Vila Nova de Gaia - Feira Medieval de Vilar de Andorinho e Invasões Francesas e Ovar - com um trabalho notável na Recriação Histórica da Visita de D. Maria II a Ovar e o Desfile de Trajes do Concelho de Ovar "O Trabalho e as Artes"), este Parque poderia vir a funcionar como um complemento dessas atividades.

Com efeito, a realização destes eventos constitui hoje um fator de dinamização e de valorização do Concelho, sendo este o conceito que se poderia incutir no Parque. Em conjunto com outros eventos, espera-se que este Parque poderia tornar-se numa ação estratégica prioritária para a promoção e para o desenvolvimento cultural e turístico do concelho, e consequente projeção do seu tecido empresarial.

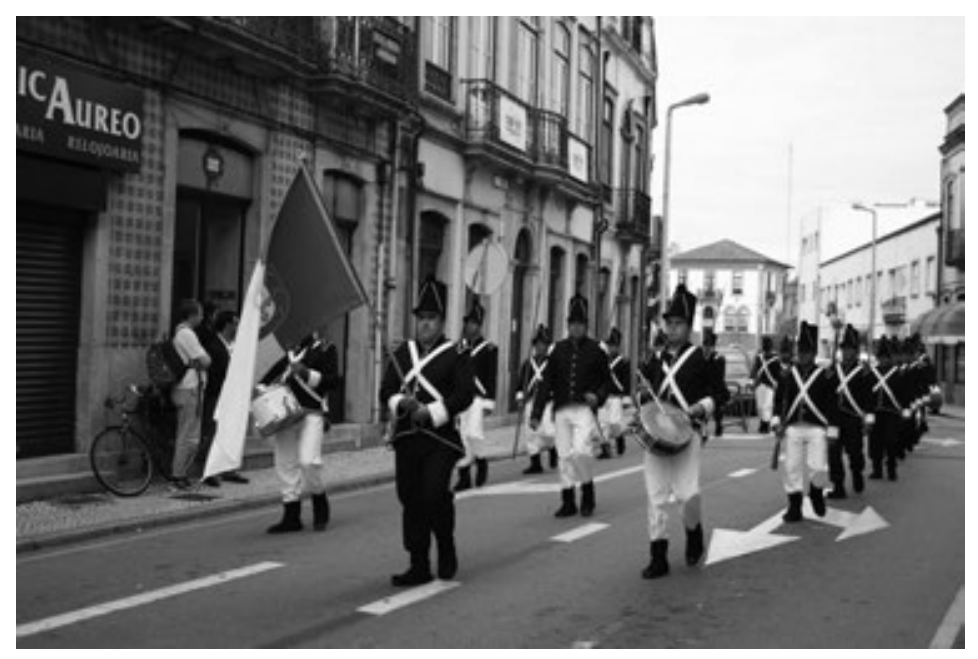

Fig. 14. Recriação Histórica da Visita de D. Maria II a Ovar, em 2009. Foto Sofia Vechina

A criação deste Parque Temático procurará oferecer ao visitante um conjunto de atividades e de equipamentos que lhe permitam, aliar à componente de diversão da visita, uma componente educativa, conhecer 
as diferentes personagens e os tipos de atividades de outros tempos, participando diretamente na recriação do "modus vivendi" da época.

Todavia é fundamental este tipo de eventos irem de encontro ao objetivo principal da Organização Mundial do Turismo (OMT) que é o "de promover e desenvolver o turismo com vista a contribuir para a expansão económica, a compreensão internacional, a paz, a prosperidade, bem como para o respeito universal e a observância dos direitos e liberdades humanas fundamentais, sem distinção de raça, sexo, língua ou religião. A Organização tomará todas as medidas necessárias para atingir este objetivo" ${ }^{17}$, porque o turismo representa a primeira indústria em muitos países, em termos da contribuição de PBI e emprego; representa um importante fator na balança de pagamentos de muitas nações; transformou-se numa fonte geradoras de emprego mais importante no mundo; é uma poderosa força para contribuir para o entendimento internacional e a paz no mundo.

Assim a OMT contribui para que todos os países maximizem os aspetos positivos do turismo bem como prevenir os seus impatos negativos, colocando em prática o Código Mundial de Ética do Turismo:

1. Contribuição do turismo para a compreensão e respeito mútuo entre homens e sociedades;

2. O turismo, vetor de desenvolvimento individual e coletivo;

3. O turismo, fator de desenvolvimento sustentável;

4. O turismo, fator de aproveitamento e enriquecimento do património cultural da humanidade;

5. O turismo, atividade benéfica para os países e comunidades de acolhimento

6. Obrigações dos atores do desenvolvimento turístico;

7. Direito ao turismo;

8. Liberdade das deslocações turísticas;

9. Direito dos trabalhadores e dos empresários da indústria turística;

10. Aplicação dos princípios do Código Mundial de Ética do Turismo

17 Artigo $3 .^{\circ}$ n. ${ }^{\circ} 1$ (Estatutos da OMT) 
Com a aplicação do Código Mundial de Ética do Turismo, poder-se-á dar um forte contributo para se atingir Objetivos de Desenvolvimento do Milénio (ODM ):

Erradicar a pobreza extrema e fome; Alcançar o ensino primário universal; Promover a igualdade de género; Reduzir a mortalidade infantil; Melhorar a saúde materna; Combater o VIH/SIDA, a malária e outras doenças; Garantir a sustentabilidade ambiental e Fortalecer uma parceria global para o desenvolvimento.

\section{Considerações finais}

Verificamos que no caso particular de Santa Maria da Feira, foram diversos fatores que contribuíram para a consolidação de projetos de recriação histórica, de "Living History" ou de "Reenactment". Por sua vez as dinâmicas obtidas permitiram a recuperação do Centro Histórico e do Vale do Cáster. Estas duas prerrogativas juntas permitem sonhar com um Parque Temático que englobe as diferentes épocas recriadas.

A tematização é sem dúvida uma das tendências a que o turismo tem aderido. Mas não vem dissociada de outros fatores e tendências que a cada dia surgem em todo o mundo. O turismo passa por transformações na mesma velocidade em que as sociedades também se transformam.

Aparentemente, esta fuga da realidade, mesmo que por algumas horas, tem levado milhares de pessoas a usufruir destes hotéis, bares, restaurantes e parques temáticos. Ressaltamos ainda, que os empreendimentos temáticos, principalmente os parques, estimulam o desenvolvimento das regiões onde estão inseridos.

No entanto, é necessário que se realizem pesquisas, de modo a oferecer subsídios ao segmento que carece ainda de maior atenção. O turismo só tem a ganhar com o fortalecimento destes empreendimentos.

As Terras de Santa Maria, pelo seu património, pela sua tradição histórica e pelos inúmeros eventos que organiza em volta das recriações históricas, e após as diversas obras de requalificação urbana dinamizadas pelos eventos, assumem-se como um lugar privilegiado para uma possível implementação de um parque temático. 


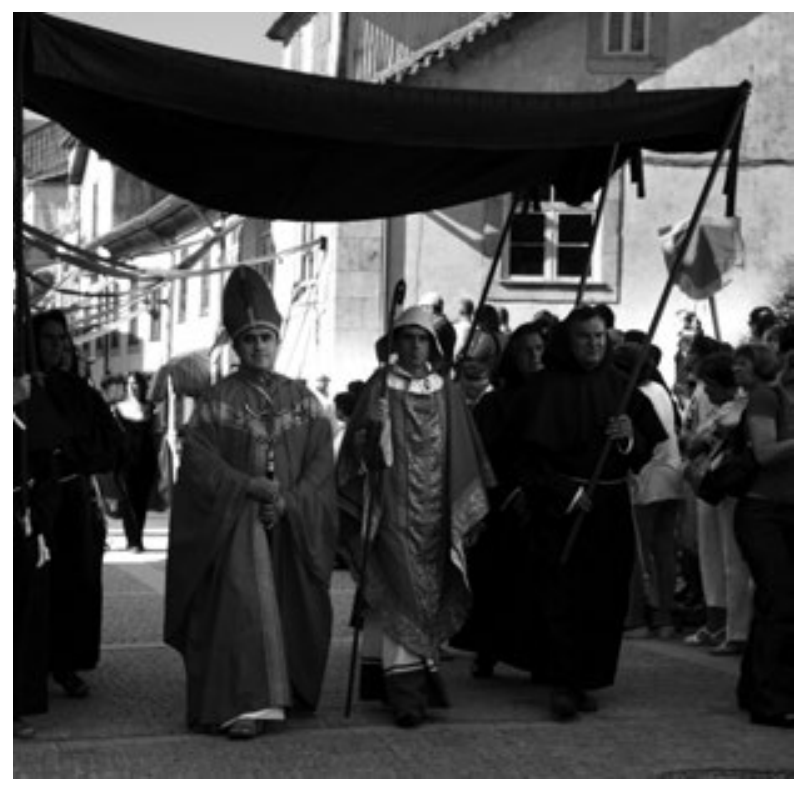

FIG. 15. Viagem Medieval em Terra de Santa Maria.

Fonte: Óscar Maia

Para que funcione da melhor forma, o parque deve procurar integrar-se da melhor maneira possível na rede de equipamentos existentes e contribuir para uma maior diversificação das atividades turísticas das Terras de Santa Maria, tentando, simultaneamente, assegurar qualidade dos serviços com a promoção de um turismo que respeite o meio ambiente.

Em género de conclusão, podemos dizer que, hoje em dia, a aposta em parques temáticos é uma aposta válida, uma vez que, aliados ao turismo temático, criam em geral, novas sinergias nas regiões ou localidades em que se instalam e podem ser utilizados para rejuvenescer os destinos turísticos tradicionais, porque atraem novos segmentos de mercado, melhoram a imagem desses destinos e diversificam a sua oferta.

Como refere Mary Ashton ${ }^{18}$, "os parques temáticos representam, boje, uma proposta de pesquisa multifacetada, ligada ao turismo, à economia,

18 Ashton, Mary Sandra G. Parques temáticos: espaços e imaginários. In: Gastal, Suzana; Gastogiovanni, Antonio Carlos (org.). Turismo na pós-modernidade (des) inquietações. Porto Alegre: Edipucrs, 2003. 
sociologia, bistória, geografia, e tantas outras áreas", permitindo a melhoria das sinergias interdisciplinares.

“Os parques temáticos históricos são os fiéis depositários do património imaterial porque apelam ao sentido de memória coletiva e exaltam os valores históricos. Neles, apesar da componente economicista, estão implícitas temáticas que fazem parte do património endógeno de uma determinada região. Os conteúdos temáticos dos parques, apesar da sua vertente de lazer, fazem referência a um passado, a uma tradição ou a uma memória que poderia ser esquecido se não existisse esta vertente" 19.

\section{Referências bibliográficas}

Ashton, Mary Sandra G. Parques temáticos: espaços e imaginários. In: Gastal, Suzana; Gastogiovanni, Antonio Carlos (org.). Turismo na pós-modernidade (des) inquietações. Porto Alegre: Edipucrs, 2003.

BÁrcia, Paula (1990), Manual de História ao Vivo, Lisboa: Ministério da Educação. Benavente, Ana (Dir.).As Inovações nas Escolas - Um roteiro de projetos, Lisboa: Instituto de Inovação Educacional. 1995.

Berens, Daniel J., Wwir Reenactment in west-central Wisconsin: context of history and memory from the last world war Eau Claire, Wiscosin MAY 2008. http://minds.wisconsin.edu/bitstream/handle/1793/28790/BerensSpring08. pdf? sequence $=2$. Acesso em 10 de Julho de 2009.

CABrita, Alexandre. Relatório acerca do $1^{\circ}$ Encontro sobre Recriação Histórica, Cultura, Turismo e Cidadania. Vendas Novas. 28 de Novembro de 2008.

CARlos, Roberto; DIAS, Francisco de Almeida, 1957-, fotogr. Viagem medieval em Terra de Santa Maria. 2002.

Castro, Jesús Pena Castro. El negocio de la historia en la Feria Medieval de Noia. Sociológica, pp: 81-100/2004.

Cravidão, Fernanda. Turismo e Desenvolvimento - o distrito de Coimbra, 19801987, separata de Arunce, Lousã.1989.

19 http://www.quintacidade.com/?p=1625. Acesso em 12 de junho de 2009. 
Cunha, Lúcio. Turismo e desenvolvimento na Raia Central. Cadernos de Geografia, 14, Coimbra, FLUC, pp. 129-138. 1995.

Dawson, Ian (1996), Standars of Living in the Middle Ages. Teaching History, 82, Editores, pp. 25-31. Editorial Verbo.

FÉlIX, Noémia. Saberes e Competências essenciais no Ensino da História, in Competências essenciais do Ensino Básico, Cadernos do CRIAP, Lisboa: Asa Editores, pp. 25-31. 2001.

GASTAL, Susana. Lugar de memória: por uma nova aproximação teórica ao património local. In: Gastal. S. (org.). Turismo investigação e crítica. São Paulo: Contexto, p. 69-81. 2002.

GiLes, Howard, "Recreating the Past for Live Events, TV, and Film: A Brief History of Reenactment. http://www.eventplan.co.uk/history_of_reenactment.htm. Acesso em 10 de Julho de 2009.

Goeldner, Charles R., Ritchie, J. R. Brent., Mcintosh, Robert W. Atrativos, Entretenimento, Recreação e Outros. In: Turismo. Princípios, Práticas e Filosofias. Trad. Roberto Cataldo Costa. 8 ed. Porto Alegre: Bookman, 2002. P.150-171. http://en.wikipedia.org/wiki/Historical_reenactment. Acesso em 8 de Julho de 2009 http://www.quintacidade.com/?p=1625. Acesso em 12 de Junho de 2009 http://www.teatro-vivarte.org/site/?page_id=2. Acesso 8 de Julho de 2009 Huyssen, Andréas. Seduzidos pela memória. Rio de Janeiro: Aeroplano, 2000. Jan., 27-30.

LANGley, Andrew. A Vida na Idade Média, Enciclopédia Visual, Lisboa: Editorial Verbo. 1999.

Lopes, Maria Virgílio Cambraia. Texto e criação Teatral na Escola, Cadernos Pedagógicos, Edições Asa. 1999.

OliveIRA, Maria do Rosário Barros. Os impactos dos eventos turísticos - o caso da Viagem Medieval em Santa Maria da Feira. 2009.

Manique, António Pedro e Proença, Maria Cândida. Didáctica da História- Património e História Local, Lisboa: Texto Editora. 1999.

Romero, Mabel Villagra. Actualidad del Asociacionismo Recreacionista en Europa: el caso italiano. $2 .^{\circ}$ Encuentro de Grupos de Recreación Histórica Medieval de Aragón, Alcañiz (Teruel). 2006.

Solé, Maria Glória Parra Santos, "A técnica de história ao vivo - a realização de uma feira medieval no Lindoso" (Didácticas e Metodologias de Ensino) Instituto 
de Estudos da Criança - Universidade do Minho. Comunicação apresentada no IV Encontro Nacional de Didácticas e Metodologias da Educação - "Percursos e Desafios", Évora, 26-28 set. 2001.

Trigo, Luiz Gonzaga Godoi. Turismo e Qualidade: tendências Contemporâneas. 6. ${ }^{\text {a }}$ ed. Campinas: Papirus, 1993. 